\title{
Estimasi Premature Mortality Cost (PMC) Penyakit Kanker Akibat Perokok Pasif di Indonesia
}

\author{
Estimation Premature Mortality Cost (PMC) of Cancer Attributable to Secondhand Smoke in Indonesia
}

\author{
Karina Anindita Santosa*, Susi Ari Kristina,Chairun Wiedyaningsih \\ Fakultas Farmasi, Universitas Gadjah Mada \\ Corresponding author: Karina Anindita Santosa; Email: karinaninditas@gmail.com \\ Submitted: 18-09-2019 Revised: 19-09-2019 Accepted: 22-09-2019
}

\begin{abstract}
ABSTRAK
Indonesia merupakan salah satu negara dengan prevalensi perokok terbesar di dunia. Tingginya angka perokok di Indonesia mengakibatkan risiko peningkatan jumlah orang terpapar atau menghirup asap rokok sebagai secondhand smoke. Secondhand smoke merupakan salah satu faktor risiko penyakit kanker. Penelitian mengenai estimasi beban penyakit kanker ini bertujuan untuk melihat seberapa besar angka kematian dan premature mortality cost penyakit kanker akibat secondhand smoke di Indonesia. Estimasi beban penyakit kanker akibat secondhand smoke merupakan penelitian epidemiologi deskriptif dan estimasi berdasarkan prevalence-based dengan indikator yang digunakan yaitu angka kematian penyakit kanker akibat secondhand smoke dan premature mortality cost. Angka kematian penyakit kanker akibat secondhand smoke (SAM) diperoleh dengan mengalikan nilai Secondhand smoke Attributable Fractions (SAFs) dengan angka kematian tiap penyakit kanker, dimana nilai SAFs diperoleh dari rumus perhitungan menggunakan data prevalensi secondhand smoke dan relative risk tiap penyakit. Premature mortality cost diperoleh dengan mengalikan angka kematian penyakit kanker akibat perokok pasif, angka harapan hidup, dan rata-rata pendapatan masyarakat Indonesia. Jumlah angka kematian tertinggi untuk penyakit kanker akibat secondhand smoke adalah kanker paru (949 kematian), kanker kolon (771 kematian), dan kanker pankreas (371 kematian). Nilai tertinggi dari premature mortality cost adalah Rp 56.882.000.000 untuk kanker paru, Rp 51.398.000.000 untuk kanker kolon, dan Rp 22.850.000.000 untuk kanker pankreas. Estimasi beban penyakit kanker akibat secondhand smoke perlu dilakukan untuk membantu pemerintah dalam menentukan program kesehatan dan untuk mengurangi beban penyakit kanker akibat secondhand smoke di Indonesia.
\end{abstract}

Kata kunci: secondhand smoke; angka kematian,; premature mortality cost; Indonesia

\section{ABSTRACT}

Indonesia is one of the countries with the largest prevalence of smokers in the world. The high number of smokers in Indonesia puts the risk of increasing the number of people exposed to secondhand smoke. The study of estimation the burden of cancer aims to see how the mortality rate and premature mortality cost of cancer due to secondhand smoke in Indonesia. This study design is an descriptive epidemiology and estimation prevalence based with indicator mortality rate of cancer related to secondhand smoke and premature mortality cost. The death rate of cancer due to secondhand smoke (SAM) is obtained by multiplying the value of secondhand smoke Attributable Fractions (SAFs) with the mortality rate of each cancer, where SAFs value are obtained from the calculation formula using the prevalence data of secondhand smoke and relative risk for each cancer. Premature mortality cost is obtained by multiplying death rates from cancer due to secondhand smoke, life expentancy, and the average income of Indonesian people. The highest total mortality's rate for secondhand smoke related cancer are lung cancer (949 deaths), colon cancer (771 deaths) and pancreatic cancer (371 deaths). The highest value of premature mortality cost are IDR 56,882 million for lung cancer, IDR 51,398 million for colon cancer, and IDR 22,850 for pancreatic cancer. Estimation the burden of cancer related to secondhand smoke needs to be done to help the government in determining health programs and to reduce the burden of cancer related to secondhand smoke in Indonesia.

Keywords: secondhand smoke; death rate; premature mortality cost; Indonesia

\section{PENDAHULUAN}

Menurut hasil Global Adults Tobacco Survey (GATS) Indonesia tahun 2011, diketahui proporsi perokok umur $>15$ tahun pada laki-laki sebesar $67 \%$ dan pada perempuan sebesar $2,7 \%$ (Ministry of Health dkk., 2011). Data Southeast Asia Tobacco Control Alliance (SATCA) melaporkan jumlah perokok di Indonesia yaitu sebesar 65.188 .338 orang dengan proporsi perokok laki-laki sebesar $66 \%$ dan perempuan sebesar 6,7\%. Tingginya jumlah konsumsi rokok tersebut menyebabkan Indonesia berada pada urutan pertama tertinggi dalam jumlah perokok usia dewasa di ASEAN (Southeast Asia Tobacco Control Alliance, 2018). Tingginya angka perokok di Indonesia mengakibatkan risiko 
peningkatan jumlah orang terpapar atau menghirup asap rokok sebagai perokok pasif. Bahan kimia yang terkandung dalam asap rokok beracun dan dapat menyebabkan berbagai penyakit seperti penyakit kanker, jantung, dan penyakit pernapasan. Dari perspektif global, tembakau membunuh lebih dari tujuh juta orang per tahun, lebih dari enam juta kematian tersebut adalah hasil dari penggunaan tembakau dari perokok, sementara sekitar 890.000 adalah hasil dari bukan perokok yang terpapar asap rokok atau secondhand smoke (Kristina dkk., 2018). Dari data monografi International Agency for Research on Cancer (IARC) yang merupakan sebuah rangkuman berbagai meta analisis mengenai penyakit kanker akibat perokok pasif menunjukkan bahwa terdapat asosiasi antara perokok pasif dengan beberapa jenis kanker yang ditunjukkan dengan relative risk (RR) dengan nilai lebih dari 1 (International Agency for Research on Cancer, 2015).

Kanker menjadi salah satu perhatian utama kesehatan masyarakat di Indonesia karena tingginya biaya perawatan dan beban substansial sejak diterapkannya program BPJS (Reich dkk., 2016). Terdapat indikator penting yang dikembangkan oleh WHO yaitu the economics of tobacco toolkit on the assessment of the economic costs of smoking. Fokus pada data kematian, pengukuran premature mortality cost penyakit kanker karena akibat secondhand smoke sangat penting untuk sebuah negara dengan prevalensi perokok yang tinggi (World Health Organization, 2011). Penelitian ini menggunakan dua indikator untuk mengukur beban secondhand smoke, yaitu secondhand smoke attributable cancer mortality (SAM) dan premature mortality cost (PMC). Berdasarkan data tersebut, dapat memberikan gambaran estimasi kerugian negara akibat kematian pasien kanker akibat secondhand smoke di Indonesia, sehingga memberikan bukti kuat kepada pemerintah bahwa faktor risiko perokok pasif memberikan dampak ekonomi yang besar serta digunakan sebagai dasar dalam upaya mencegah terjadinya peningkatan jumlah populasi secondhand smoke.

\section{METODOLOGI}

Penelitian ini merupakan penelitian epidemiologi deskriptif dan estimasi berdasarkan prevalence-based dengan rincian per penyakit kanker. Penelitian ini mengkaji beban penyakit kanker akibat perokok pasif dengan menggunakan indikator yaitu premature mortality cost (PMC) penyakit kanker akibat secondhand smoke. Estimasi premature mortality cost (PMC) penyakit kanker akibat secondhand smoke di Indonesia diperoleh melalui empat langkah. Langkah pertama adalah menentukan penyakit kanker yang disebabkan secondhand smoke. Langkah kedua adalah menghitung secondhand smoke attributable fractions (SAFs) yang diperoleh dari rumus perhitungan menggunakan data prevalensi secondhand smoke dan relative risk tiap penyakit. .Langkah ketiga adalah menghitung angka kematian penyakit kanker akibat secondhand smoke (SAM) diperoleh dengan mengalikan nilai secondhand smoke attributable fractions (SAFs) dengan angka kematian tiap penyakit kanker. Langkah keempat, menghitung premature mortality cost diperoleh dengan mengalikan angka kematian penyakit kanker akibat perokok pasif, angka harapan hidup, dan rata-rata pendapatan masyarakat Indonesia.

\section{Sumber Data}

Prevalensi perokok pasif di Indonesia : prevalensi perokok pasif di Indonesia berdasarkan jenis kelamin diperoleh dari Global Adult Tobacco Survey: Indonesia Report 2011 (Ministry of Health dkk., 2011). Relative risks (RR) : RR diperoloh dari monografi International Agency for Research on Cancer (IARC) yang dikeluarkan WHO (International Agency for Research on Cancer, 2015). Angka kematian kanker di Indonesia : angka kematian karena kanker per kelompok umur dan jenis kelamin diperoleh dari data BPJS tahun 2018 untuk Indonesia. Angka harapan hidup : angka harapan hidup masyarakat Indonesia didapat dari WHO Life Tables tahun 2016 (World Health Organization, 2016). Rata-rata pendapatan : rata-rata pendapatan penduduk Indonesia per jenis kelamin didapat dari Badan Pusat Statistik tahun 2018.

\section{Penentuan Jenis Kanker}

Penentuan jenis kanker didasarkan pada studi epidemiologi dari publikasi IARC yang menekankan pada dampak perokok pasif dapat menyebabkan beberapa jenis kanker. Adapun 6 jenis penyakit kanker akibat perokok pasif yang dianalisa dalam penelitian ini yang diperoleh dari monografi IARC tahun 2015 yang dikeluarkan oleh WHO yaitu kanker paru, 
Karina Anindita Santosa, et al

Tabel I. Relative Risks (RR) dan Secondhand smoke Attributable Fractions (SAFs) penyakit kanker akibat secondhand smoke

\begin{tabular}{llcccc}
\hline \multirow{2}{*}{ ICD-10* $^{*}$} & \multirow{2}{*}{ Jenis Kanker } & \multicolumn{2}{c}{ Relative Risks } & \multicolumn{2}{c}{ SAFs** (\%) } \\
\cline { 3 - 6 } & & Laki-Laki & Perempuan & Laki-Laki & Perempuan \\
\hline C33-34 & Paru & 2,28 & 1,31 & 50,90 & 18,86 \\
C18-21 & Kolon & 1,90 & 1,80 & 42,16 & 37,50 \\
C16 & Perut & 5,80 & 5,89 & 79,54 & 78,57 \\
C22-24 & Kandung Kemih & 1,75 & 3,30 & 37,79 & 63,30 \\
C25 & Pankreas & 6,00 & 6,00 & 80,19 & 78,94 \\
C32 & Laring & 2,90 & 2,90 & 60,61 & 58,76 \\
\hline
\end{tabular}

*ICD-10, International Classification Diseases $10^{\text {th }}$ **SAFs, Secondhand smoke Attributable Fractions

kanker kolon, kanke perut, kanker kandung kemih, kanker pankreas, dan kanker laring.

\section{Estimasi Secondhand smoke Attributable Fractions (SAFs)}

Secondhand smoke Atributable Fractions (SAFs) merupakan proporsi jumlah kematian kanker akibat dari secondhand smoke. Rumus SAFs terdiri dari 2 komponen utama yakni, prevalensi perokok pasif di populasi nasional yang didapat dari GATS 2011 dan relative risk (RR) didapat dari monografi International Agency for Research on Cancer (IARC). Rumus SAFs sebagai berikut:

$$
\text { SAFS }=\frac{p(R R i-1)}{1+p(R R i-1)}
$$

nilai $\mathrm{p}$ adalah prevalensi perokok pasif, nilai RR ialah relative risk, dan $i$ adalah sub-scrip kategori penyakit tertentu (World Health Organization, 2011)

\section{Estimasi Secondhand smoke Attributable Mortality (SAM)}

Secondhand smoke attributable mortality (SAM) merupakan angka kematian akibat secondhand smoke diperoleh dengan mengalikan nilai SAFs dengan proporsi angka kematian masing-masing penyakit kanker akibat secondhand smoke dari data BPJS tahun 2018 per kelompok umur (usia 16 tahun sampai 75 tahun) dan jenis kelamin.

\section{Premature Mortality Cost}

Estimasi premature mortality cost diperoleh dengan mengalikan angka kematian penyakit kanker akibat perokok pasif, angka harapan hidup, dan rata-rata pendapatan masyarakat Indonesia. Angka harapan hidup penduduk Indonesia menggunakan data dari
WHO Life Tables tahun 2016, sedangkan ratarata pendapatan masyarakat Indonesia per jenis kelamin diperoleh dari Badan Pusat Statistik tahun 2018. Penghasilan rata-rata per bulan adalah Rp 3.064.920 untuk laki-laki dan Rp 2.398.674 untuk perempuan.

\section{HASIL DAN PEMBAHASAN}

Nilai relative risks (RR) dan SAFs kanker dapat dilihat pada Tabel I. Seperti yang ditunjukkan pada Tabel I, secondhand smoke berkaitan sebesar 80,19\% kanker pada laki-laki di Indonesia, sementara menyumbang sebesar 78,94\% pada perempuan di Indonesia. Nilai SAFs tertinggi untuk laki-laki adalah kanker pankreas $(80,19 \%)$, peringkat kedua adalah kanker perut $(79,54 \%)$, dan peringkat ketiga adalah kanker laring $(60,61 \%)$. Nilai SAFs tertinggi untuk perempuan adalah kanker pankreas $(78,94 \%)$, peringkat kedua adalah kanker perut $(78,57 \%)$, dan peringkat ketiga adalah kanker kandung kemih $(63,30 \%)$.

Tabel II menunjukkan angka kematian kanker akibat secondhand smoke (SAM) dan premature mortality cost (PMC). Angka kematian kanker akibat secondhand smoke terbesar pada laki-laki adalah kanker paru (810 kematian), diikuti oleh kanker kolon (445 kematian), dan kanker pankreas (197 kematian). Angka kematian kanker akibat secondhand smoke terbesar pada perempuan adalah kanker kolon (326 kematian), diikuti oleh kanker pankreas (174 kematian), dan kanker paru (139 kematian). Nilai premature mortality cost terbesar penyakit kanker akibat secondhand smoke pada laki-laki adalah kanker paru (Rp 48.647.000.000), diikuti oleh kanker kolon (Rp 30.147.000.000), dan kanker pankreas (Rp 12.463.000.000). Nilai premature mortality cost terbesar penyakit kanker akibat 
Tabel II. Secondhand smoke Attributable Mortality (SAM) dan Premature Mortality Cost (PMC) penyakit kanker akibat secondhand smoke di Indonesia

\begin{tabular}{llccrrr}
\hline \multirow{2}{*}{ ICD-10* } & \multirow{2}{*}{ Jenis Kanker } & \multicolumn{2}{c}{ SAM $^{* *}$} & \multicolumn{3}{c}{ PMC*** (Juta Rupiah) } \\
\cline { 3 - 6 } & & Laki-Laki & Perempuan & Laki-Laki & Perempuan & Total \\
\hline C 33-34 & Paru & 810 & 139 & 48.647 & 8.235 & 56.882 \\
C 18-21 & Kolon & 445 & 326 & 30.147 & 21.251 & 51.398 \\
C 16 & Perut & 93 & 51 & 5.940 & 3.362 & 9.302 \\
C 22-24 & Kandung Kemih & 94 & 55 & 5.621 & 3.093 & 8.714 \\
C 25 & Pankreas & 197 & 174 & 12.463 & 10.387 & 22.850 \\
C 32 & Laring & 53 & 8 & 3.041 & 524 & 3.565 \\
& Total & 1.692 & 753 & 105.859 & 46.852 & 152.711 \\
\hline
\end{tabular}

*ICD-10, International Classification Diseases $10^{\text {th }}$ **SAM, Secondhand smoke Attributable Mortality, ***PMC, Premature Mortality Cost

secondhand smoke pada perempuan adalah kanker kolon (Rp 21.251.000.000), diikuti oleh kanker pankreas (Rp 10.387.000.000), dan kanker paru (Rp 8.235.000.000).

Total kematian penyakit kanker akibat secondhand smoke di Indonesia pada laki-laki sebanyak 1.692 kematian dan pada perempuan sebanyak 753 kematian. Hasil penelitian ini menunjukkan bahwa total premature mortality cost penyakit kanker akibat secondhand smoke di Indonesia pada laki-laki sebesar $\mathrm{Rp}$ 105.859.000.000, lebih besar daripada total premature mortality cost penyakit kanker akibat secondhand smoke di Indonesia pada perempuan yaitu sebesar Rp 46.852.000.000. Nilai tertinggi dari total premature mortality cost berdasarkan jenis kanker adalah Rp 56.882.000.000 untuk kanker paru, Rp 51.398.000.000 untuk kanker kolon, dan Rp 22.850.000.000 untuk kanker pankreas. Oleh karena itu, kebijakan terkait pengendalian rokok dapat dipertimbangkan di Indonesia untuk mengurangi jumlah perokok dan perokok pasif, seperti larangan merokok di tempat umum maupun di tempat kerja.

Penelitian tentang premature mortality cost penyakit kanker yang disebabkan oleh secondhand smoke masih sangat terbatas. Penelitian mengenai estimasi premature mortality cost penyakit kanker yang disebabkan oleh perilaku merokok pernah dilakukan sebelumnya di Indonesia oleh (Kristina dkk., 2015), didapatkan hasil nilai premature mortality cost kanker paru pada laki-laki di Indonesia tahun sebesar Rp 898.504.000 dan pada perempuan sebesar Rp 222.018.000.000. Paparan secondhand smoke telah diidentifikasi sebagai faktor risiko berbagai kanker yang berhubungan dengan sistem pernapasan, terutama kanker paru-paru. Penelitian (Asomaning dkk., 2008), melaporkan bahwa orang yang terpapar asap rokok memiliki risiko lebih tinggi terkena kanker paru-paru daripada perokok aktif. Partikel asap rokok yang menumpuk di paru-paru melalui sistem pernapasan dapat menyebabkan pertukaran kromosom, kerusakan oksidatif DNA, dan meningkatkan jumlah mutasi P53 pada kanker paru-paru.

Penelitian ini menegaskan bahwa prevalensi secondhand smoke yang tinggi dapat menimbulkan beban ekonomi yang substansial serta dampak kesehatan masyarakat yang cukup besar. Ada beberapa batasan yang harus diperhatikan pada penelitian ini. Pertama, RR yang digunakan dalam penelitian ini tidak terbatas pada populasi ASEAN. Studi lebih lanjut yang meneliti risiko kanker terkait perokok pasif harus dilakukan di antara populasi ASEAN untuk estimasi yang lebih valid. Kedua, data kematian yang digunakan adalah data dari BPJS tahun 2018 di mana belum semua masyarakat Indonesia mengikuti BPJS. Selain itu, biaya kematian dini penyakit kanker akibat secondhand smoke, tidak semua komponen biaya yang terkait seperti biaya kecacatan terkait kanker, pengeluaran perawatan kesehatan dalam pengobatan kanker dimasukkan.

Sebagai kesimpulan, merokok memberikan dampak biaya kesehatan dan keuangan yang substansial pada masyarakat. Berdasarkan prevalensi, analisis penyakit spesifik yang dijelaskan dalam penelitian ini menunjukkan dengan jelas bahwa dampak kesehatan dan ekonomi dari kanker akibat 
secondhand smoke di Indonesia sangat dramatis, dan harus dikurangi dengan menerapkan kebijakan pengendalian tembakau dan program kesehatan untuk mengurangi prevalensi merokok dan perokok pasif di Indonesia sehingga dapat mengurangi beban penyakit kanker akibat secondhand smoke di Indonesia.

\section{KESIMPULAN}

Total premature mortality cost penyakit kanker akibat secondhand smoke di Indonesia pada laki-laki sebesar Rp 105.859.000.000 dan perempuan sebesar Rp 46.852.000.000. Nilai tertinggi dari premature mortality cost adalah Rp 56.882.000.000 untuk kanker paru, Rp 51.398.000.000 untuk kanker kolon, dan Rp 22.850.000.000 untuk kanker pankreas. Estimasi beban penyakit kanker akibat secondhand smoke perlu dilakukan untuk membantu pemerintah dalam menentukan program kesehatan dan untuk mengurangi beban penyakit kanker akibat secondhand smoke di Indonesia.

\section{UCAPAN TERIMA KASIH}

Ucapan terima kasih kepada Badan Penyelenggara Jaminan Sosial (BPJS) yang telah berkenan dalam memberikan data dan pihakpihak lain yang tidak bisa disebutkan satupersatu yang telah membantu dalam penelitian ini.

\section{DAFTAR PUSTAKA}

Asomaning, K., Miller, D.P., Liu, G., Wain, J.C., Lynch, T.J., Su, L., dkk., 2008. Second hand smoke, age of exposure and lung cancer risk. Lung Cancer, 61: 13-20.

International Agency for Research on Cancer, 2015. International Agency for Researcher on Cancer Monographs on the Evaluations of Carcinogenic Risks to Humans-SecondHand Tobacco Smoke. WHO Library Cataloguing-in-Publication Data, Paris.

Kristina, S.A., Endarti, D., Prabandari, Y.S., Ahsan, A., dan Thavorncharoensap, M., 2015. Burden of Cancers Related to Smoking among the Indonesian Population: Premature Mortality Costs and Years of Potential Life Lost. Asian Pacific Journal of Cancer Prevention, 16: 6903-6908.

Kristina, S.A., Endarti, D., Wiedyaningsih, C., Fahamsya, A., dan Faizah, N., 2018. Health Care Cost of Noncommunicable Diseases Related to Smoking in Indonesia, 2015. Asia Pacific Journal of Public Health, 30: 29-35.

Ministry of Health, R. of I., World Health Organization, dan Regional Office for South-East Asia, 2011. Global Adult Tobacco Survey: Indonesia Report 2011. World Health Organization, Regional Office for South East Asia, New Delhi.

Reich, M.R., Harris, J., Ikegami, N., Maeda, A., Cashin, C., Araujo, E.C., dkk., 2016. Moving towards universal health coverage: lessons from 11 country studies. The Lancet, 387: 811-816.

Southeast Asia Tobacco Control Alliance, 2018. The Tobacco Control Atlas: ASEAN Region, Fourth Edition 144.

World Health Organization, 2011. Assessment of the Economic Costs of Smoking. WHO Library Cataloguing-in-Publication Data, Geneva, Switzerland.

World Health Organization, 2016. Global Health Observatory Data Respiratory, Life Expectancy: Life Tables Indonesia [Online]. Geneva, Switzerland: WHO. 